\title{
Nature-oriented potential resource and melliferous value of forest belts in steppe agro-forest landscapes
}

\author{
Irina Samsonova ${ }^{1} \bowtie$, Anatoly Gryazkin ${ }^{1}$, Natalia Belyaeva ${ }^{1}$, Vladimir Belyaev $^{2}$, \\ Vitaliy Petrik ${ }^{2}$, Veronica Bespalova ${ }^{1}$, Alexander Lyubimov ${ }^{1}$ \\ ${ }^{1}$ Saint-Petersburg State Forest Technical University named after S.M. Kirov, Institutsky per. 5, Saint-Petersburg, Russia, \\ phone: +789819084598, e-mail: isamsonova18@mail.ru \\ ${ }^{2}$ Northern Arctic Federal University named after M.V. Lomonosov, Severnaya Dvina Emb. 17, Arkhangelsk, Russia
}

\section{Abstract}

Creation of forest shelterbelts in steppe zone is important because they allow to obtain the highest yields of grains of cereals where the area of the most favorable conditions for growth is formed in comparison with many other soilclimatic regions. Melliferous and pollen production value of lands changes as a result of anthropic landscape conversion from agrarian to forest agrarian. There are a lot of melliferous trees and shrubs in forest belts; some of them have been introduced from the other floristic regions and are well naturalised in the local conditions. Nature-oriented potential resource of forest belts is in carbon deposition and oxygen production by phytomass of the main species.

The aim of the research is to evaluate the bioresource potential of forest belts in the conditions of steppe agrarian landscapes. Bioresource potential ( $B r p$ ) of forests for honey supply in the region was defined according to the distribution of species in the area. Potential honey stock of melliferous lands, represented by forest stands was assigned according to their area, given by the Forestry Department of Rostov region, and the average normative honey productivity of 1 ha of these crops. The number of beehives $(N)$ necessary for honey supply that use $1 / 2$ of bioresource forest potential was calculated according to the need of a bee family in honey per year. Value of nature-oriented resource of black locust (Robinia pseudoacacia) stands was defined according to the amount of oxygen produced and carbon deposed. Pure and mixed forest belts with the share of black locust from 60 to $80 \%(335.0-494.5 \mathrm{~kg} / \mathrm{ha})$ in composition with ash (Fraxinus sp.), Norway maple, Siberian elm (Ulmus pumila), apricot and dense structure of honey suckle and Siberian pea tree underbrush have the highest productivity. The total volume of possible honey yield from forest belts of agro-forest landscapes in the studied region is 26,379.8 t. Maximum indices of carbon fixation and oxygen production are observed in the maturing stands of black locust, and the largest honey stock dominate in average age stands and are 3,755,000 t, 10,288,000 t and 25,200 t, respectively. The role of the whole system in the increase of landscape honey productivity and formation of forage conveyor for bees and enthomophages might be much more if the recommended assortment of the best melliferous and pollen bearing species would be more completely used when forest belts are created.

\section{KeY WORDS}

black locust, carbon deposition, forest belts, honey stock, oxygen production, stands 


\section{INTRODUCTION}

For a long time, the greatest tasks and challenges in forestry have been related to meeting the basic needs of people, including wood, water, food, bioenergy, biodiversity, and recreation (Westoby 1987; Sands 2005; Calder 2007). According to the current Forest Code (art. 32, $34,39)$, forest resources are non-woody, food and others. In agro-forest reclamation, when resources of forest belts are evaluated, meliorative (increase of agricultural crop yield), productive (stand stock) and nature-oriented (oxygen production and carbon deposition by trees) resources are taken into consideration.

In the steppe area of the river Don region, the forest shelterbelt management is of great importance because this territory is highly exposed to destruction by water and wind erosion. One million and three thousand hectares of lands in the region are exposed to wind erosion, dust storms take place once in 3-4 years, and dry winds are also frequent (Parakin 1971). Influence of forest shelterbelts on agro-forest landscapes is necessary to consider in the context of stand adaptation to environmental factors. The main theoretical concept of adaptive forest reclamation of agrarian landscapes developed by V.M. Ivonin (2008) is to withstand desertification by forest reclamation system when stands adapt to environmental factors and to widen adaptive possibilities of cultivated plants. Resistance, productivity, biodiversity of agrarian landscapes and their technical compounds increase while plant biomass with carbon fixation, oxygen production and metabolic utilization of anthropic pollutants grows (Ivonin 2008). The most significant feature that defines the efficiency of forest belts as well as any other producing biotic component of natural system is their productivity - phytomass - energy equivalent, the result of concentration of its fluxes in biosphere. Pavlovskij (2004) pointed out that 'studying of phytomass of forest shelterbelts is important for evaluation of its stocks as well as secondary productivity (forage, food, medicine and others)'. Carbon deposition and oxygen production take place in the period of stand biomass formation. Element composition of the organic part of wood substance of different tree species is practically equal: $49-50 \%$ of carbon, $43-44 \%$ of oxygen, about $6 \%$ of hydrogen and $0.1-0.3 \%$ of nitrogen in relation to the mass of absolutely dry wood. Knowledge of phytomass supply allows to determine carbon supply, considering that 11 tons of dry biomass of timber, branches and roots contain $0.5 \mathrm{t}$ of carbon (Isaev et al. 1993). Carbon fixation and oxygen production by black locust stand in steppe conditions were studied by Arkhangelskaya (2007). Microclimate conditions and hydrological regime of the territory changed drastically as the result of forest shelterbelt system creation. It favours vegetation of entomophilous crops, and their nectar productivity increases in particular. According to the observations carried out by Lazarev and Mukha (1989), honey productivity of the landscape converted from agrarian to forest-agrarian in Uryupinsk district of Volgograd region increased due to introduction of the best melliferous plant species to shelterbelts. Honey productivity of these species considering their participation in the stand and nectar bearing sustainability is in total $3.77 \mathrm{t}$ per 100 ha of shelterbelts and it is $0.11 \mathrm{t}$ per 100 ha of farmlands (with afforestation of 3\%).In the work of Samsonova and Dobrynina (2013), it was noted that sustainable development of bee breeding and forestry in modern conditions is based on wide usage of biological and ecological potential of plants and their system formations - biocommunity. An important role in implementing this task play questions of studying and exploitation of melliferous resources. Hundreds of valuable melliferous plants grow in the Rostov region, but plant resources are studied insufficiently, and it has a negative influenceon the development of bee breeding and its productivity. Growing of forest belts with species composition of melliferous plants providing sustaining honey supply is very important for the increase of bee family survival and forage stock conservation. Dzybov and Chashchin (1984) have evaluated that if the maximum distance for honey yield source supporting its optimal usage is taken as $2 \mathrm{~km}$, each apiary may have about 26 ha of woody, shrubby and herbal melliferous plants in the given location of forest shelterbelts of Stavropol territory. It is enough for the keeping of 40-50 bee families at one place. Ivonin (2008) identified meliorative role of forest shelterbelts in agro-forest landscapes as multifunctional, which is expressed in some aspects such as global ecologicalmeliorative, protective-meliorative, social-meliorative, sanitary-hygienic and economical. While ecologically sustainable forest management practices are becoming more acceptable than traditional forestry methods in many parts of the world, international organisations 
need to place increased emphasis on the international benefits of forests and forest products (carbon sequestration, protection of water quality, prevention of erosion, provision of recreation, provision of habitats for endangered plant and animal species, supply of wood and natural products, including energy) in their public materials so that the drive for changes comes from the general public rather than from the forest owners (Lee et al. 2011).

Samsonova (2014), the areas of honey-bearing lands were determined for forest reclamation in the Rostov region and the output of marketable honey in the protective forest belts.

The aim of the research is to evaluate the bioresource potential of forest belts in the conditions of steppe agrarian landscapes.

To achieve this goal, the following tasks were identified:

- study of the species composition of the honeybearing resources of forest belts in the conditions of steppe agro-forest landscapes;

- determination of the bioresource potential of the honey-bearing areas of agro-forest landscapes, honey stock of forest belts and the number of bee colonies that can be kept on the studied forage lands;

- determination of carbon stocks and production of oxygen from forest belts in conditions of steppe agro-forest landscapes.

\section{MAterial AND MEthodS}

The objects of research were forest belts of Verkhnedonsky, Remontnensky, Semikarakorsk, Salsk, Zavetninsky, Zimovnikovsky, Matveyev-Kurgan, RodionoNesvetaevsky, Neklinovsky, Oktyabrsky and Aksai districts of the Rostov region of Southern Federal District of Russia. Studies were carried out using data of a single inventory of forest shelterbelts in 2006. Typical shelterbelts identified as the result of analysis of forest survey were chosen by evaluating the productivity resources.

To determine the potential honey store of shelterbelts and the number of bee families that it is possible to keep on the studied forage lands, age structure and species composition of melliferous plants of forest belts of Rostov region were analysed.
To define honey productivity of shelterbelts, test plots in forest belts of various composition of melliferous plants in tree and understory were placed (2009-2011). Quantitative registration of melliferous plants on melliferous lands also has done (by the method of line referenceroutes). Gryazkin (1997) offers to study ground cover on round plots with radius of $1.785 \mathrm{~m}$. Registration plots should adjoin each other to form transect.

Taxonomic indicators such as plants, construction type, width and number of shelterbelt rows were registered, and potential honey productivity was calculated. Pure (11 forest strips) and mixed (22 forest strips) stands were analysed. Sugar productivity of black locust of different age was considered to define honey productivity of black locust forest belts. For other types of honey plants, the average indicators of sugar production were considered were determined.

Honey productivity $(M)$ of melliferous lands on one hectare of territory was evaluated considering that 100 parts of honey contain 80 parts of sugar and 20 parts of water, that is, sugar productivity $\left(X_{c}\right)$ of a certain melliferous plant on one hectare was multiplied on 1.25 and magnitude of potential honey productivity on a unit of area $(\mathrm{kg} / \mathrm{ha})$ was calculated according to the formula 1 (Nesterov et al. 1988):

$$
M=1.25 X_{c}
$$

Bioresource potential $\left(B_{r p}\right)$ of forests for the supply of honey of the area was defined with regard to the distribution of forest area and forest belts. Areas of melliferous lands $\left(S_{1}\right)$ were consistently multiplied on their sugar productivity $\left(X_{c}\right)$. Obtained figures were summed up and forest bioresource potential for honey yield was calculated according to the formula 2 (Sidarenko et al. 2010):

$$
B_{r p}=S_{1} X_{c 1}+S_{2} X_{c 2}+S_{3} X_{c 3}+\ldots+\ldots S_{n} X c_{n}
$$

where:

$S_{1}, S_{2}, S_{3}, \ldots, S_{n} \quad$ - areas (ha) of growing of particular forest species and agricultural crops (melliferous);

$X_{c 1}, X_{c 2}, X_{c 3}, \ldots, X_{c n}$ - sugar productivity ( $\left.\mathrm{kg} / \mathrm{ha}\right)$ of separate forest species and melliferous agricultural crops. 


\section{sciendo}

While calculating honey stock of the region (district), it was regarded that bees usually collect only a part of nectar produced by plants - from $1 / 3$ to $1 / 2$. Forest bioresource potential cannot be used fully because:

a) a part of nectar is collected by other insects

b) bees cannot visit all melliferous plants and flowers

c) of unfavourable weather conditions

Honey stock - the amount of honey that can actually be collected by bees from the area with honey plants.

Honey supply period or season, during which bees collect nectar from plants.

Honey yield - the isolation of nectar by melliferous plants in nature.

Honey stock $(P)$ (was calculated according to the formula 3 (Sidarenko et al. 2010):

$$
P=0.625 B_{r p}
$$

where:

0.625 - a coefficient (regarding conversion of sugar to honey (honey from nectar of the main nectar bearing plants contains about $80 \%$ of sugar) if half of forest bioresource potential is used for honey yield $\left(0.5 \times 1.25 B_{r p}\right)$.

Potential honey supplies of melliferous lands represented by forest plantations was defined out of actual stand area given by the Department of Forestry of Rostov region as well as from average normative of honey productivity from one hectare of these crops.

Beehive number $(N)$ required for honey yield of half of the forest bioresource potential was calculated taking into account the need for honey of a bee family per year, which in average is $90 \mathrm{~kg}$ and $30 \mathrm{~kg}$ (the bee family for procorm consumes $90 \mathrm{~kg}$ of honey per year and must give $30 \mathrm{~kg}$ of marketable honey) provisional getting of marketable honey in the sum of $120 \mathrm{~kg}$, according to the formula:

$$
N=0.625 B_{r p} / 120
$$

The total volume of timber, roots, branches, leaves (biomass) was calculated according to the formula 4 offered by Gitarsky (2006) in conversion to carbon $\left(C_{t}\right)$ :

$$
C_{t}=\sum_{i j}\left[V_{i j} \times E F_{i j}\right] \times C F
$$

where:

$V_{i j} \quad$ - species supply $I$ of age group $j, \mathrm{~m}^{3} /$ ha (Ivonin 2010);

$E F_{i j}$ - the coefficient of conversion of species stand supply $i$ of age group $j, \mathrm{t} / \mathrm{m}^{3}$ (Zamolodchikov et al. 2003; Isaev et al. 1993);

$C F$ - proportion of carbon in $1 \mathrm{t}$ of wood dry substance $(0.5)$.

To convert the supplies of black locust stands to their biomass coefficients $\left(E F_{i j}\right)$ for young stands as 1.28; of middle aged -0.999 ; under mature -1.01 ; mature and over mature -1.041 were used. Summarised biomass in conversion to oxygen, according to corresponding registration year $\left(C_{t}\right)$, was calculated by the formula 5 :

$$
C_{t}=\sum_{i j}\left[V_{i j} \times E F_{i j}\right] \times O F
$$

where:

$O F$ - oxygen equivalent for studied species equal to 1.37 (Belov1983).

\section{ResUlts AND DISCUSSION}

Nowadays, the agricultural lands of the region are 240,212 ha of forest shelterbelts (Ivonin 2010). Dominating distance between forest belts is $400-500 \mathrm{~m}$; between the secondary (transverse) belts, it is $1,500-2,000 \mathrm{~m}$. The width of forest belts is from 3 to $44 \mathrm{~m}$ (2-14 rows).

Till the age of 20-25 years old, forest belts of $14 \mathrm{~m}$ width are of open construction, belts with width over $14 \mathrm{~m}$ are of dense construction (up to 50 years). Planting scheme for forest belts of the European white elm was $4.0 \times 1.5 \mathrm{~m}$, of oak $-3.0 \times 1.5 \mathrm{~m}$; for black locust stands it was $1.8 \times 1.5 \mathrm{~m} ; 2.5 \times 1.0 \mathrm{~m} ; 2.5 \times 2.0 \mathrm{~m} ; 1.5 \times 1.0 \mathrm{~m}$; $2.0 \times 1.0 \mathrm{~m} ; 2.5 \times 1.5 \mathrm{~m}$ or $2.0 \times 1.2 \mathrm{~m}$.

Forest belts are of great interest for beekeeping. The main melliferous species of forest belts is black locust with planting area of $83.0 \%$ (116,866 ha) in relation to the total area of shelterbelts of Rostov region.

Siberian elm (Ulmu spumila L.) takes the second position by the occupied area of agro-forest landscapes - 11.4\% (15,986.5 ha). English oak and threethorned acacia occupy $3.9 \%(5,564.16 \mathrm{ha})$ and $1.7 \%$ 
$(2,327.29$ ha). Other tree and shrub species are also valuable as melliferous plants. However, they are introduced in small numbers to forest belts as, and therefore, can provide only sustaining honey supply (Samsonova 2013).

Siberian elm is one of the most widely cultivated tree species in steppe silviculture. According to Sidarenko (2000), Siberian elm suppresses black locust in forest reclamation stands even if their percentage is equal.

Shade-tolerant shrubs with early flushing are the best associates of black locust, their presence contributes to obtaining of highly productive honey supply. They are Tatarian honeysuckle, field maple (Acer campestre L.) and Tatarian maple, red dogwood (Swida sanguinea L.), golden currant (Ribes aureum Pushs) and others. Tree-shrub type of mixing of black locust and gold currant is also good in drought conditions. Quick growth, tolerance to soil conditions, frost and drought resistance make currant one of the most valuable shrub species for protective silviculture. Gold currant positively influences black locust (Baboshko 2011).

Siberian acacia is characterised by good growth, high resistance and long life in drought steppe conditions on different soils and is used in forest shelterbelts. Mixing with Siberian pea tree negatively influences black locust.

Three-thorned acacia flowers in forest shelterbelts at the end of May. Its nectar is weakly used by bees, because its flowering coincides with the flowering of holly clover (Onobrychis), which is more preferred by bees.

Our studies have shown that forest shelterbelts consisting of pure black locust grow badly and become sparse. So, two shelterbelts, № 22 and № 31at the age of 20 years old, located in the Aksai district of Rostov region were studied, and better growth and condition of black locust was defined. In the first forest belt, black locust was mixed with tree and shrub species according to the following scheme: the first (from the south), the second, the ninth rows are of black locust, the third and the forth are of green ash (Fraxinus pennsylvanica Marsh), Siberian pea tree, the fifth, the sixth are of black locust, Tatarian honeysuckle, Siberian pea tree, the seventh row is of green ash, Tatarian honeysuckle, the eighth row is of green ash. The second forest belt consists of pure black locust. Studied forest belts were in identical conditions of location, created by the same agrarian technique, planting placement of both the forest belts is $1.5 \times 0.8 \mathrm{~m}$. The difference is only in species composition of these two forest belts.

Analysis of inventory parameters of black locust forest belts shows this species has better growth by height and diameter in all age periods in the first forest belt where it is mixed with green ash, Tatarian honeysuckle and Siberian pea tree.

Black locust stands with green ash in composition are characterized by low canopy density that influences the growth of steppe grass types under the canopy, mainly of beans, mint family, cruciferous and composite family. Projective covering of grass layer of forest belts, according to our assessment, is $85-95 \%$, where there are many melliferous plants such as German inula (Inula helenium L.), cornflower (Centaurea diffusa Lam.), bishop's-wort (Stachys recta), Steppe sage (Salvia stepposa Schost), purple hagtaper (Verbascum phoeniceum), Austria angel's-eye (Veronica austriaca).

Formation of agrarian biogeocenosis of a forest belt depends on the species composition of arboreous and shrub layers, rate of their growth, intensity of natural entry of grass seeds and presence among them, together with annual and biennial weeds, representatives of local flora, mainly of dominant perennials.

Species composition of grass cover changes with the age of stands. Data of some studies show that grass cover in artificial stands passes a number of stages.

During the first stage (non-forest or wild grass), vegetation development occurs in early period of stand growth (before closing of crowns). Weed species dominate in young stands. During the next 5-10 years they are replaced by rhizomatous, creeping-rooted and taprooted perennials, among which are such melliferous plants as thistle (Cirsium incanum), old-man's-pepper (Achillea nobilis), Irish daisy (Taraxacum officinale), blue dandelion (Cichorium intybus), plaster clover (Melilotus officinalis), lilac sage (Salvia verticillata), Geneva bugleweed (Ajuga genevensis) and others. By the age of 15-20 years old, cereals prevail in grass stand composition. At this age, the melliferous plants of forest belts are represented by bean tree (Prunus tenella), British inula (Inula britannica), meadow clover (Trifolium pratense) and honey clover, alfalfa (Medicago romani- 


\section{sciendo}

ca), hop-clover (M. lupulina), Marshall thyme (Thymus marschallianus), wood sage (Salvia nemorosa) and other species of local flora. In this period, cenosis becomes stable and diverse. It allows planning to set the apiaries. Weed steppe and steppe plants such as woodruff ( $\mathrm{As}$ perula prostrate), knap weed, steppe sage, and in more humid places meadow-steppe and meadow species start to introduce to older stands.

Impending natural formation of grass layer in forest belts that lasts for 20-40 years may be replaced by the active creation of artificial community, where depending on the purpose, melliferous or other economically valuable (medicine, forage) grasses will dominate.

As the result of carried out studies, it was defined that the highest honey productivity may be provided by pure $(612.0 \mathrm{~kg} / \mathrm{ha})$ and mixed forest belts with $60-80 \%$ of black locust (335.0-494.5 kg/ha) of dense construction with ash, ash-leaved maple and apricot, and with Tatarian honeysuckle and Siberian pea tree in understory. Forest belts with $20-50 \%$ of black locust together with Siberian elm (178 kg/ha), three-thorned acacia $(195 \mathrm{~kg} / \mathrm{ha})$, green ash $(281.3 \mathrm{~kg} / \mathrm{ha})$ and English oak $(153.0 \mathrm{~kg} / \mathrm{ha})$ are characterized by significant honey productivity and are of great interest for beekeeping.
Our studies show that a young group of forest belts is represented by black locust $(2.8 \%)$.

The most part of all forest belts in Rostov region $(83.3 \%)$ is of middle-aged group, among which, the main melliferous plant (Robinia) of steppe area of the river Don occupies the largest area (80\%). Undermature forest belts are represented mainly by European oak (2.9\%), Siberian elm (5.6\%); mature and over mature stands make up 5.4\%.

Evaluation of bioresource potential of forest belts regarding black locust sugar productivity according to age periods show (Tab. 1) that the largest actual honey stock can be taken from melliferous plants of forest belts in agro-forest landscapes. Black locust produces $41,481.2$ tons, that is $98.3 \%$ of the total honey stock. Elms (383.6 t), three-thorned acacia (297.9 t) and English oak (44.5 t) are characterised by less productivity. The total bioresource potential for honey supply of forest belts of the studied region is $42207.34 \mathrm{t}$ (Samsonova 2014).

Evaluation of deposed carbon and produced oxygen by forest belts was done on the basis of the total species phytomass, which was calculated according to the data of species growth in forest reclamation districts of investigation (Ivonin 2010).

Table 1. Honey stock of agro-forest landscapes of Rostov region very long title

\begin{tabular}{|c|c|c|c|c|c|c|}
\hline \multirow{2}{*}{$\begin{array}{l}\text { Melliferous } \\
\text { plant species }\end{array}$} & \multirow{2}{*}{$\begin{array}{c}\text { Total area of } \\
\text { stands, } \\
\text { ha }\end{array}$} & \multirow{2}{*}{$\begin{array}{l}\text { Total honey } \\
\text { productivity, } \\
\text { t }\end{array}$} & \multirow{2}{*}{$\begin{array}{c}\text { Bioresource } \\
\text { potential, } \\
\mathrm{t}\end{array}$} & \multicolumn{2}{|c|}{$\begin{array}{c}\text { Exploitation honey stock, } \\
\mathrm{t}\end{array}$} & \multirow{2}{*}{$\begin{array}{c}\text { Calculated } \\
\text { number of bee } \\
\text { families }\end{array}$} \\
\hline & & & & $\mathrm{T}$ & $\%$ & \\
\hline Black locust & $116,866.4$ & $51,851.6$ & $41,481.2$ & $25,925.9$ & 98.3 & 216,048 \\
\hline Elm & $15,986.5$ & 479.5 & 383.6 & 239.8 & 0.93 & 1,999 \\
\hline Oak & $5,564.16$ & 55.5 & 44.5 & 27.9 & 0.125 & 232 \\
\hline Three-thorned acacia & $2,327.29$ & 372.4 & 297.9 & 186.2 & 0.73 & 1,551 \\
\hline Total & $140,744.4$ & $52,759.0$ & $42,207.2$ & $26,379.8$ & 100.085 & 219,830 \\
\hline
\end{tabular}

Table2. Carbon deposition and oxygen production by black locust of Rostov region

\begin{tabular}{|l|c|c|c|c|c|c|}
\hline \multicolumn{1}{|c|}{ Age group } & $\begin{array}{c}\text { Area, } \\
\text { ha }\end{array}$ & $\begin{array}{c}\text { Timber supply, } \\
\mathrm{m}^{3}\end{array}$ & $\begin{array}{c}\text { Biomass, } \\
\mathrm{t}\end{array}$ & $\begin{array}{c}\text { Carbon } \\
\text { deposition, } \\
\mathrm{t}\end{array}$ & $\begin{array}{c}\text { Oxygen } \\
\text { production, } \\
\mathrm{t}\end{array}$ & $\begin{array}{c}\text { Honey stock, } \\
\mathrm{t}\end{array}$ \\
\hline \multicolumn{7}{|c|}{ Forest belts } \\
\hline Young & $4,083.73$ & $34,651.07$ & $44,353.36$ & $22,176.69$ & $60,764.1$ & 666.47 \\
\hline Middle-aged & $112,641.4$ & $7,517,542$ & $7,510,023$ & $3,755,012$ & $10,288,734$ & $25,244.35$ \\
\hline Under mature & 141.26 & $7,467.5$ & $7,474.98$ & $3,737.49$ & $10,240.7$ & 23.91 \\
\hline Total & $116,866.4$ & $7,559,661.0$ & $7,561,851.0$ & $3,780,926.0$ & $10,359,738.0$ & $25,934.73$ \\
\hline
\end{tabular}


Evaluation of carbon supplies and oxygen production on agricultural lands was done according to the area of black locust stands.

Data analysis of Table 2 and Figure 1 shows that the highest indices of carbon fixation and oxygen production by black locust stands are found in the middle aged stands $(3,755,000 \mathrm{t}$ and $10,288,000 \mathrm{t})$. Mature and over mature age groups are absent in the forest belts of Rostov region.

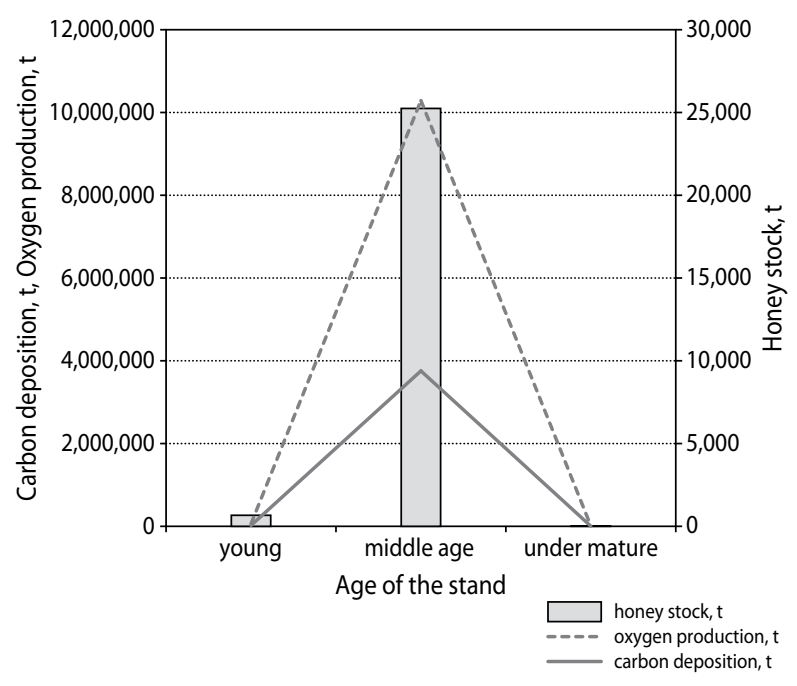

Figure 1. Proportion of honey stock and photosynthesising functions of black locust stands on the area of Rostov region

According to the observations conducted by V.V. Tanyukevich (2015), oak forest belts depose the largest amount of carbon - 133-229 t/ha - by the age of maturity. Elm, ash and three-thorned acacia forest belts are able to store carbon in their phytomass in amounts of $78 \mathrm{t} / \mathrm{ha}, 91 \mathrm{t} / \mathrm{ha}$ and $87 \mathrm{t} /$ ha respectively. The amount of carbon that poplar (Populus) forest belts are able to store, changes from 41 to $35 \mathrm{t}$ per hectare.

The highest amount of oxygen is produced by forest belts formed by oak, black locus stand ash (627 t/ha, $378 \mathrm{t} /$ ha and $249 \mathrm{t} /$ ha respectively). Productivity of elm forest belts makes up $85 \mathrm{t} /$ ha of stands.

Thus, estimating the melliferous value of forest belts, it should be considered that creation of the most effective and longlived forest belts with black locust as the main species is characterised by the proper species composition and schemes of mixing. Predominant species are the European white elm (Ulmus laevis Pall.), black locust (Robinia pseudoacacia L.), three-thorned acacia (Gleditsia triacanthos L.), English oak (Quercus robur L.), Norway maple (Acer platanoides L.), ashleaf maple (A. negundo L.), tatarian maple (Acer tataricum L.),wild apple (Malus sylvestris Mill.), apricot (Prunus armeniaca L.) and wild pear (Pyrus communis subsp. Pyraster L.). Shrubs such as Siberian pea tree (Caragana arborescens Lam.), Tatarian honeysuckle (Lonicera tatarica L.) and Russian olive (Elaeagnus angustifolia L.) have been introduced.

The largest actual honey stock can be obtained from the pseudo-acrobation roster of $25,926,000 t-98.3 \%$ of the total honey stock, which is represented by the middle-aged stands and is $80 \%$ of the total area of forest belts.

Significant values of carbon fixation and oxygen production by robin stands are observed in the middleaged $(3,755,000 \mathrm{t}$ and $10,288,000 \mathrm{t})$ stands.

\section{Conclusion}

Black locust stands in conditions of agrarian landscapes produce a huge amount of nectar -up to 500 $\mathrm{kg}$ per hectare of pure stands during favourable years. However, due to short period of flowering, unfavourable weather conditions at this time, spread of forest belts outside the limits of bee migration and remoteness of belts from each other in width (1500-2000 m), nectar supply of black locust stands is used insufficiently in beekeeping.

Full usage of melliferous plants in forest belts depends on the local types of honey supply and movement apiary possibility. For remote steppe areas, far from forests and natural vegetation of gullies, the usage of melliferous plants of forest belts is of great importance in preparation of apiaries for the main honey supply from buckwheat (Fagopyrum), coriander (Coriandrum sativum) and sunflower (Helianthus annuus). Flowering of trees and shrubs, depending on their species composition, take place from April to June, the period of intense increase of power by bee family. Flowering of many melliferous herbs continues in forest belts in July and even in August.

In further planting of new forest belts and reconstruction of old ones, it is recommended to use the mentioned assortment of the best nectar bearing and pollen bearing tree and shrub species more fully. 
Under global ecological meliorative role of stands is under stood their participating in so-called photosphere, which through the process of photosynthesis globally influences the ecology of the Earth and its distinct regions.

Protective and meliorative role of forest belts is in controlling of water regime, microclimate of agro-forest landscapes, decreasing the damage by water erosion and deflation and increasing the biodiversity of lands. Social and meliorative role of forest shelterbelts is expressed in the improvement of living and working conditions of people. Sanitary hygienic role is in phytoncide display, oxygen production and carbon deposition.

Economic role is in the forest belt resources of agro-forest landscapes - to be more exact, in productive resources (timber), meliorative (yield increase) and nonwoody resources (honey productivity, medicine raw material and others).

\section{References}

Arkhangelskaya, G. 2007. The role of protective forest stands in carbon dioxide fixation. The role and place of agroforestry in the modern Society: Materials of Intern. scientific and practical conference dedicated to the 75th anniversary of VNIALMI, 10-13 October 2006, Volgograd, 346-353 (in Russian).

Baboshko, O. 2011. Improved on black locust (Robinia) protective stands in steppe landscapes of the North Caucasus (in Russian). Scientific Journal Cube GAU, 72 (08), 1-10.

Belov, S. 1983. Forestry (in Russian). Tutorial, Moscow.

Don, K., Lee, N.E. Koch, J., Innesand, P.M. 2012. Emerging issues in forest science. Folia ForestaliaPolonica, Series A - Forestry, 2011, 53 (1), 52-63.

Calder, I.R. 2007. Forests and water - ensuring forest benefits outweigh water costs. Forest Ecology and Management, 251, 110-120.

Dzybov, D.T., Chashchin, Y.A. 1984. Honey plant shelterbelts (in Russian). Beekeeping, 1, 15.

Gitarsky, M., Zamolodchikov, D., Korovin, G. 2006. Emission and absorption of greenhouse gases in the forests of Russia in connection with the performance of obligations under the UN climate confer- ence (in Russian). Silviculture Forest Science, 6, 34-44.

Gryazkin, A.V. 1997. Pat. 2084129. The Russian Federation, MCI C 6 A 01 G 23/00. The method of undergrowth accounting (in Russian). No 94022328/13; declared 10/06/94; publ. 07.20.97, Bul. Number 20.

Isaev, A., Korovin, G., Utkin, A. 1993. Evaluation of reserves and the annual carbon sequestration in biomass of Russian forest ecosystems (in Russian). Forest Science, 6, 3-10.

Ivonin, V. 2008. Theory of adaptive afforestation of agricultural landscapes. Problems in increase the productivity of reclaimed lands. Proceedings of the international scientific and practical conference (in Russian). NSMA, Novocherkassk, 105-114.

Ivonin V., Tanyukevich V. 2010.Tables of growth of the main species of forest belts of the Rostov region (forest managers recommendations) (in Russian). NSMA, Novocherkassk.

Lazarev, M., Mukha, T. 1989. Effect of afforestation on nectar stock (in Russian). Agriculture, 3, 34-35.

Nesterov, P. Pinchuk, L., Leontyak, G. 1988. Melliferous resources of Moldova (in Russian). Kishinev.

Parakin, V. 1971. Features of growth and condition of black locust plantations in protective stands on the North Azov chernozems of the Rostov region (in Russian). Tr. NIMI, Novocherkassk, 13 (9), 141-147.

Pavlovskij, E.S. 2004. Encyclopedia of forest drainage (in Russian). VNIALMI, Volgograd.

Samsonova, I., Dobrynin, N. 2013. Improvement of the bioresource potential of the mellifields nectariferous land in the steppe area of the river Don region (in Russian). Russian Herald. Acad. agricultural Sciences, 4, 37-39.

Samsonova, I. 2014. Honey-producing value of shelterbelts in the steppe agrofores t landscapes (in Russian). Beekeeping, 1, 8-11.

Sands, R. 2005. Forestry in a Global Context. CABI Publishing, Wallingford, UK.

Sidarenko, P., Bakhilova, O. 2000. Features of black locust growth in mixed stands (in Russian). Forestry, $1,22-23$.

Sidarenko, P., Samsonova, I., Bogdanova, I., Malashchuk, V., Vlasenko, A., Sidorenko, D., Zhukov, R. 2010. Evaluation. use and improvement of bioresource potential of forests and farmlands for honey production in the Rostov region (in Russian). Sci- 
entific-method recommendations. NGMA, Novocherkassk.

Tanyukevich, V. 2015. Meliorative role of phytomass of forest belts of steppe agrolandscapes of the Middle and Lower Don region (in Russian). Abstract for the degree of Doctor of Agriculture Science, Volgograd.
Westoby, J. 1987. The purpose of forests. Basil Blackwell, Oxford, UK.

Zamolodchikov, D., Utkin, A., Chestnykh, O. 2003. Conversion rates of the stand stock in phytomass of the main forest-forming species in Russia.Krasnoyarsk. Russian forest inventory and forest management, 1 (32), 119-127. 